Explanation of Plate 7.

Fig. I. Cluster of oenocytes from a nearly mature Phryganeid larva. o, oenocytes; $t$, large tracheal branch; $t$, smaller tracheal ramifications; $h$, tracheal hypodermis.

Fig. 2. A nearly mature embryo of Xiphidium ensiferum. oo, oenocyte clusters seen from the surface through the integument; $a$, pleuropodium of the right side (appendage of the first abdominal segment); $s$, styli (belonging to the ninth abdominal segment; the specimen being a male); $c$, cerci.

Fig. 3. Part of a transverse section through the first abdominal segment of a young embryo of Blatta (Phyllodromia) germanica. $v$, pleural ectoderm ; $o$, oenocytes ; $a$, pleuropodium ; $i$, coelomic cavity; $u$, entoderm ; $w$, nervecord ; $e$, fat-body ; $b$, blood-corpuscle ; $d$, diverticulurn of the coelomic wall, which in appendage-bearing segments becomes converted into the limb-musculature but in this segment atrophies.

Fig. 4. Part of a transverse section through one of the abdominal segments of a Rlasturus nymph; o, oenocytes; $h h$, hypodermal cells; $r$, chitinous cuticle; $e e$, fat-body ; $b b$, blood-corpuscles; $m$, tergo-sternal muscles; $n$, muscles in cross-section.

\title{
TACHINID PARASITE OF EUCATERVA VARIARIA GROTE, AND OTHER NOTES.
}

\section{BY C. H. TYLER TOWNSEND, LAS CRUCES, N. MEX.}

Along the arroyos on the mesa-lands, and near the bases of mountain ranges, in southern New Mexico, may be found growing large tree-like shrubs, with willow-like leaves, and bearing in spring numbers of rather large pink flowers, which are followed by catalpa-like seedpods. This is known to botanists as Chilopsis saligna.* In August these shrubs are well stocked with the cocoons of a moth, Eucaterva variaria Grote, the larvae of which feed upon the leaves. The identification was made by Dr. Henry Skinner, to whom I sent a specimen of the moth. The cocoons are very lightly spun of silk, binding

\footnotetext{
* I am indebted to Professor E. O. Wooton, of the New Mexico Agricultural College, for the name.
}

the leaves together to form a part of them, and are formed on the terminal shoots. From one of these cocoons, there issued, about the $4^{\text {th }}$ or $5^{\text {th }}$ of September, a $\delta$ specimen of a Tachinid, which I can in no way distinguish from the $\delta$ of Hyphantrophaga hyphantriae Twns. The parasite issued without going into earth, as there was none of the latter in the jar in which the cocoons were placed, but came directly from the cocoon of the moth, in which, if I remember rightly, the puparium of the Tachinid was found. This is quite a different habit from that possessed by those members of the same species which parasitize the Fall webworm; perhaps the latter individuals 
emerge from the earth solely because the Hyphantria cocoons are placed therein, though I have found the puparium separate from the cocoon in the earth.

Mr. Harrison G. Dyar, to whom I sent one of the Eucaterva cocoons from which the moth had emerged, wrote me as follows concerning two Tachinid eggs which he found within it, and which are doubtless those of the above species :

"There were two eggs of Tachina upon the cast skin contained in the cocoon, and both had hatched but apparently had failed to enter the larva. Probably they are eggs of the species of Tachina you have bred from the cocoons. They are elliptic ovate in outline, flat below and rounded above, smooth shining white. Under the microscope, they appear very faintly divided into minute hexagonal or circular areas. Length $0.6 \mathrm{~mm}$., width $0.3 \mathrm{~mm}$.

"'The larvae had hatched by breaking a piece off of the pointed end. The eggs had been placed upon the body of the caterpillar, not on the head."

Meigenia websteri Twns., Can. entom.. xxiii, 206. This species was recorded as bred from a chrysalis. Professor Webster sent me a portion of the chrysalis, and it has since been determined, by Dr. Henry Skinner, as belonging to Pyrameis cardui. Re- garding the generic position of this Tachinid, it does not belong in Meigenia. The best place to which I can, with my present knowlege, relegate it, is in the genus Prospherysa v. d. W. Dr. Brauer, in a letter to me, has referred it with a query to Achaetoneura. Phorocera (Meigenia) promiscua Twns. should perhaps be referred to the same genus as the preceding. It is indicated by Brauer in litt. as belonging either to Achaetoneura or Prosopaea. If these genera can be used, it will be well to recognize them.

Tachina clisiocampae Twns. is referred by Brauer in litt. to Eutachina. This I do not approve of, as there is no necessity for the creation of the new genus Eutachina to contain the forms referred to Tachina sensu stricto.

I would like also here to make a note of the fact that Dr. Brauer informs me by letter, as also in a note of his in the Sitzungsber. k. k. zool.-bot. gesellsch. Wien, of May, I891, that he first called attention to the relationship of the Oestridae with the Muscidae in $185^{8}$, in the Verh. zool.-bot. gesellsch. I wish, therefore, to correct my statement in the Proc. ent. soc. Washn. ii, 9o, that this view was first advanced by Loew.

\section{THE LARVA OF SARROTHRIPA REVEYANA.}

BY HARRISON G. DYAR, YOSEMITE, CAI.

The larva of this species occurred abundantly on poplar at Yosemite, Cal., in July. The moths emerged the same season in August and I obtained them at this time in 1889 and 1891 . When I first noticed the larvae living grega- 

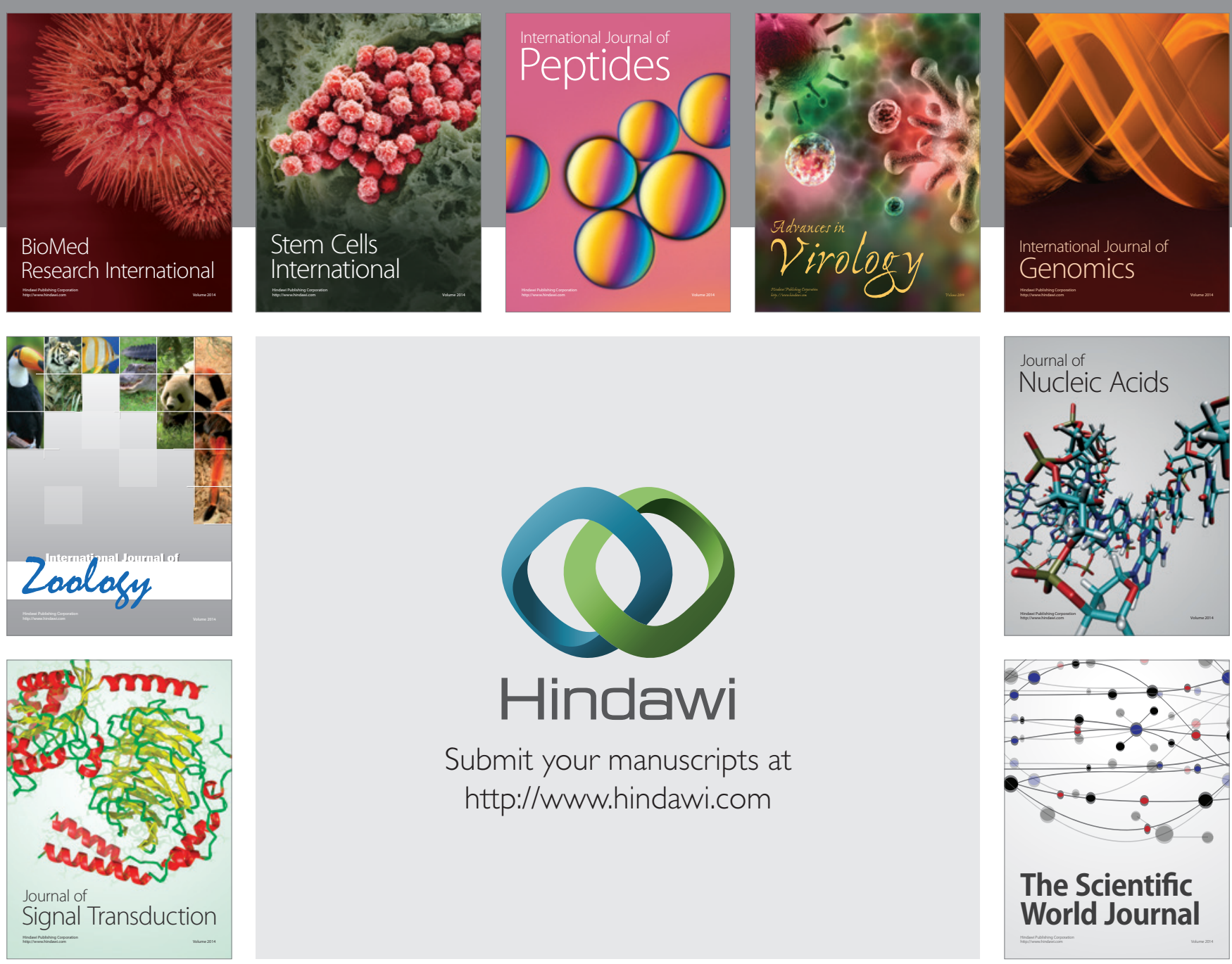

Submit your manuscripts at

http://www.hindawi.com
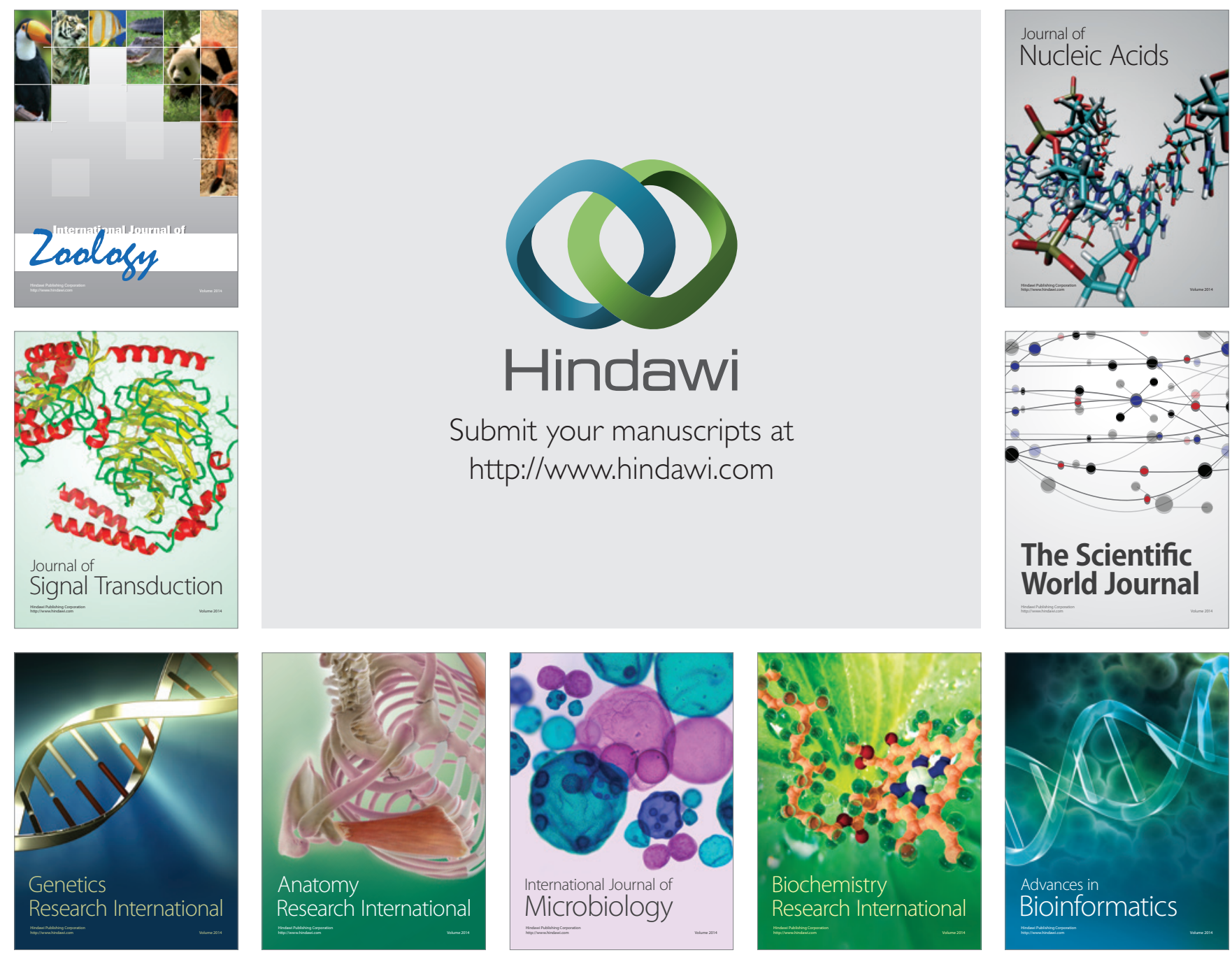

The Scientific World Journal
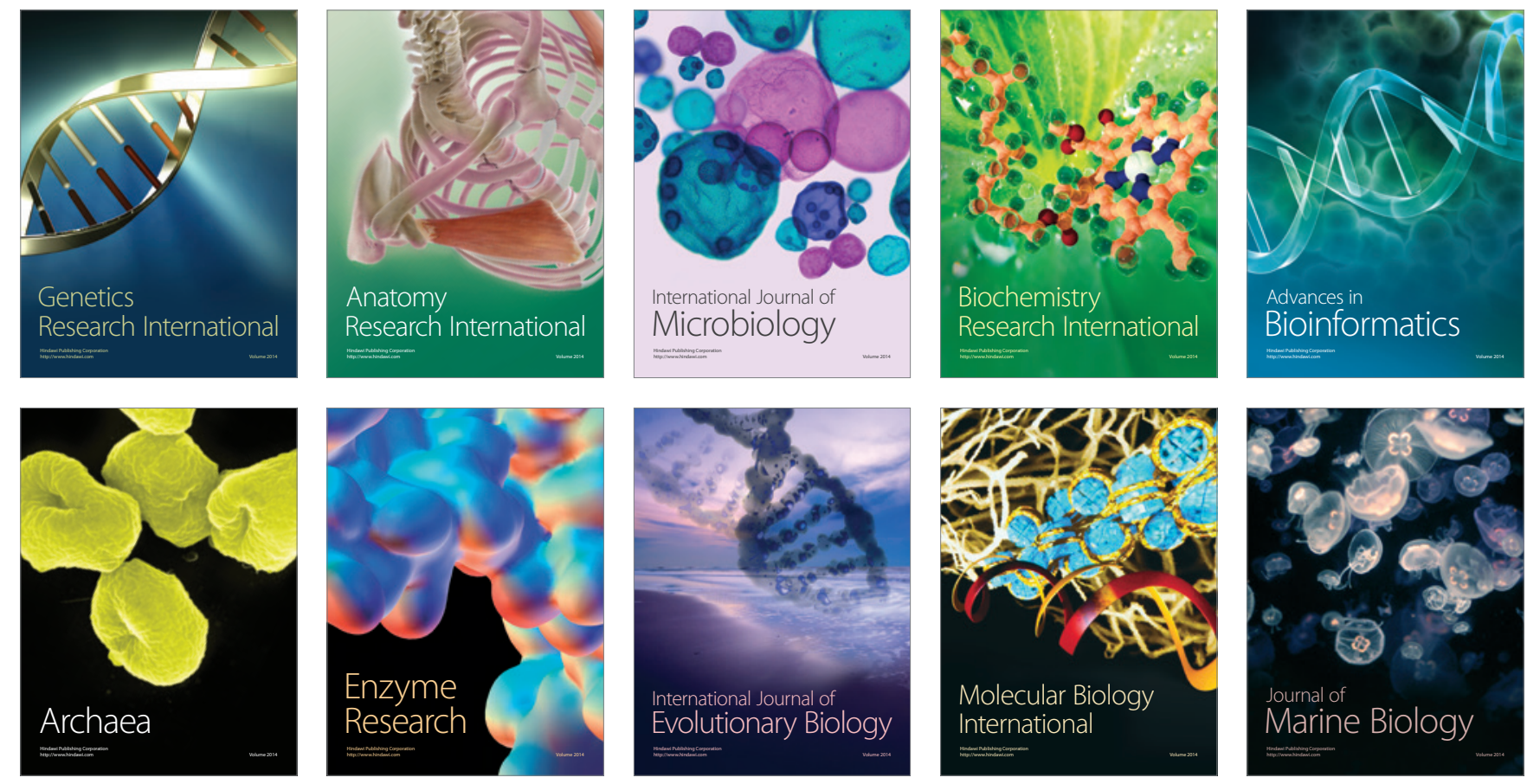